\title{
Allelopathic effect of the Cladonia verticillaris lichen extracts and fumarprotocetraric acid on the early growth of germinated seedlings in Allium cepa L.
}

\author{
Yano-Melo A. M. ${ }^{1}$; Vicente, C. ${ }^{2}$; Xavier- Filho L. ${ }^{3}$ \\ 1.Dept ${ }^{\circ}$ Micologia , C.C.B., Universidade Federal de Pernambuco, Recife, 50670-710, Brazil \\ 2.Laboratory of Plant Physiology, Faculty of Biology, Complutense University of Madrid, \\ Spain \\ 3.Centro de Ciências Biológicas e da Saúde-Instituto de Tecnologia e Pesquisa - 49015- \\ 070 , Aracaju-Sergipe-Brazil
}

\begin{abstract}
Summary: The allelopathic activity of the different type of Cladonia verticillaris lichen extracts and fumarprotocetraric acid on the early growth of A. серa (IPA 6) germinated seedlings depends on their chemical composition and concentration, respectively. It was observed that the length of the radicle was significantly stimulated by fumarprotocetraric acid at high concentrations and by the total extract of C. verticillaris thalli, which contained high level of fumarprotocetraric, acid confirmed by HPLC - technique. In addition, it was found, that the phosphate buffer extract, which contained high level of methy $\beta$-orcinol carboxilate measured by HPLC, significantly reduced the length of the hypocotyls. Under our experimental conditions there was no influence of different type of extract and fumarprotocetraric acid on the seed germination ratio of A. cepa, in relation to control. From the study of HPLC it was found that fumarprotocetraric acid and methy $\beta$-orcinol carboxilate were present in all extracts at different concentrations, according to the method of extraction.
\end{abstract}

Abbreviations: $\mathrm{HPCL}=$ high performance liquid chromatographic, i.d. $=$ inner diamater, $\mathrm{UV}=$ ultraviolet, FUM= fumarprotocetraric acid. 


\section{Introduction}

The lichens, as a group of the symbiotic organisms, composed by the association of seaweed (generally Cyanobacteria and Chlorophyta) and fungi (most Ascomycetes and few Basidiomycetes), produce a range of secondary compounds, most of which specific (Rundel, 1978). Among these substances produced by symbiosis, there are depsides, depsidones, dibenzofurans and usnic acid. Some of these products originated from the secondary metabolism of lichens, possibly play an importance role in its physiology, besides defense characteristic. The fumarprotocetraric acid is an aldehyde derivative form of depsidones, of the series meta of the type $\beta$-orcinol (Huneck, 1973), present in the medullae of lichenic thallus (Huovinen et al., 1990) Some works refer to this acid as responsible for pedogenesis in rockysites, where the lichens are present (Schatz, 1963 and Syers, 1969). Despite being one the lichenic acids more soluble (Iskandar and Syers, 1971), it is leached in the soil in little amount due to its medullar localization (Garcia-Junceda and Xavier-Filho, 1986). Other works emphasize its importance against colds, bronchitis, asthma and gastric disorders (Huovinen et al., 1983), on the ecology field, (Reutimann and Scheidegger 1987) found that the lichens which produce the fumarprotocetraric acid were rejected by mites on the alimentary diet. Furthemore, Giez et al. (1994), showing that fumarprotocetraric acid, when fed to neonate larvae during the first six days of their development, caused a pronounced increase of the larval period and/or a high incidence of developmental malformations, indicating deleterious long term effects. Molisch in 1937 defined allelopathy as the detrimental effects of one plant species (the donor) on the process of germination, growth, or development of another plant species (the recipient) (Putnam, 1985). Furthemore, Rice (1974, cit. Roger and Ocaña, 1992), declare that this effect can be stimulatory, inhibitory on the concentration.

Up to now, few works were carried out showing the allelopathic activity of the lichens (Pyatt, 1967; Brown and Mikola, 1974; Dauriac and Rondon, 1976; Fisher, 1979; Whiton and Lawrey,
1982,1984 and Goldner et al., 1986). However, works about fumarprotocetraric acid and allelopathy are few. The goal of the present work was to study the allelopathy influence of different extracts obtained from $C$. verticillaris and of the fumarprotocetraric acid on the germination and early growth of $A$. cepa seedlings.

Materials and methods

\section{Preparations of lichenic extracts}

The following extracts were prepared: aqueous, phosphate buffer and total from $C$. verticillaris. Samples of $20 \mathrm{~g}$ of lichenic thallus dried at room temperature $\left(28^{\circ} \mathrm{C}\right)$ were pulverised and utilised for preparation of extracts. The procedures for obtaining the aqueous and buffered extracts were similar, differing only in the solvents utilised, constituted, respectively, of distilled water and phosphate buffer $50 \mathrm{mM}$ in $\mathrm{pH} 7.0$. For the total extract, the following solvents were used: ethylic ether $\circledR$ acetone $®$ ethanol: water $(8: 2 \mathrm{v} / \mathrm{v})$. All solvents remained in shaker with the lichenic thallus for one hour. The preparation of the total extract was done by cold percolation, utilising the solvents in increasing order of the polarity for a better extraction of the substances present in the thallus.

\section{Germination tests}

The following concentrations of fumarprotocetraric acid were used: $72.6 \mathrm{mM}, 290.6 \mathrm{mM}$ and $726.7 \mathrm{mM}$. The concentration of extracts was 127 $\mathrm{mg} / \mathrm{l}$, corresponding to $290.6 \mathrm{mM}$ of fumarprotocetraric acid in the total extract, according to the HPLC results. The onion (Allium cepa cv. IPA 6) seeds were placed and germinated in Gerbox plates containing filter paper (100 seeds in each Gerbox plate, for each replication), under laboratory conditions $\left(+/-28^{\circ} \mathrm{C}\right.$, diffused natural light). The evolutions were performed on the sixth and tenth day after the start of the experiment, being the following parameters evaluated: germination rate, and radicle and hypocotyl length. The experimental design was completely randomised, with four replications. 
Table 1 - Germination rates of Allium capa L. (cv. IPA 6) seeds with

fumarprotocetraric acid and Cladonia verticillaris extracts.

TREATMENTS GERMINATION RATE $(\%)$

$\begin{array}{lll}\text { 1. FUM - 290.6mM } & 96.0 & \mathrm{a} \\ \text { 2. FUM - 72.6mM } & 95.75 & \mathrm{a} \\ \text { 3. Phosphate buffer } & 95.25 & \mathrm{a} \mathrm{b} \\ \text { 4. Total extractl } & 94.75 & \mathrm{a} \mathrm{b} \\ \text { 5. FUM - 726.7mM } & 93.75 & \mathrm{a} \mathrm{b} \\ \text { 6. Control } & 93.5 & \mathrm{a} \mathrm{b} \\ \text { 7. Aqueous extract } & 91.25 & \mathrm{~b}\end{array}$

means followed by the same letter do not differ statistically by the Tukey test $(0,05)$.

Isolation and purification of the fumarprotocetraric acid

The fumarprotocetraric acid was isolated from C. verticillaris with $20 \mathrm{~g}$ of the pulverised lichenic thallus by the methodology of (Asahina and Shibata 1954).

\section{HPLC of the lichenic extracts}

The chomatographic analyses were performed in a VARIAM 5000 apparatus, under the following conditions RP-C8 column of $40 \times 0.4$ $\mathrm{cm}$ i.d., mobile phase acetonitril: acetic acid $(80: 20 \mathrm{v} / \mathrm{v})$ : water $(98: 2 \mathrm{v} / \mathrm{v})$, flux of $0.3 \mathrm{~cm} / \mathrm{min}$., $26^{\circ} \mathrm{C}$ of temperature, $84 \mathrm{~atm}$ of pressure and $\mathrm{UV}$ detector at $280 \mathrm{~nm}$.

\section{Results}

\section{Germination tests}

Germination rate - The $C$. verticillaris extracts and fumarprotocetraric acid neither showed inhibitory nor stimulatory effect on the germination rate of A. серa. Despite the percentage values of the phosphate buffer and total extracts, respectively $95.26 \%$ and $94.75 \%$, being above the ones obtained in the control
(93.5\%), they were not significantly different by the Turkey test (Table 1).

Radicle lenght-The evaluation of radicle length showed growth stimulus in the treatment with fumarprotocetraric acid at $726.7 \mu \mathrm{M}$ and $290.6 \mu \mathrm{M}$ concentrations and in the total extract, since they exhibited values significantly greater than the control. The other treatments also showed values in radicle length, greater than those found in the control, despite not statistically significant (Table 2).

Hypocotyl length - The results obtained in this parameter were not similar to those obtained in the radicle length. The evaluation of hypocotyl lenght showed in the treatment with phosphate buffer extract, since it exhibited value significantly lower than the control. On the contrary, however, there is no evident response of stimulating effect of fumarprotocetraric acid. Although the concentrations of $290.6 \mu \mathrm{M}$ AND $726.7 \mu \mathrm{M}$ have shown higher values than the control, they were not statistically significant (Table 2)

Chemical composition of the extracts

Aqueous extract - The aqueous extract was basically composed of two substances: $58.1 \%$ of 
Table 2 - Mean radicle lenght of Allium cepa L. (cv. IPA 6) with fumarprotocetraric acid and C.verticillaris extracts.

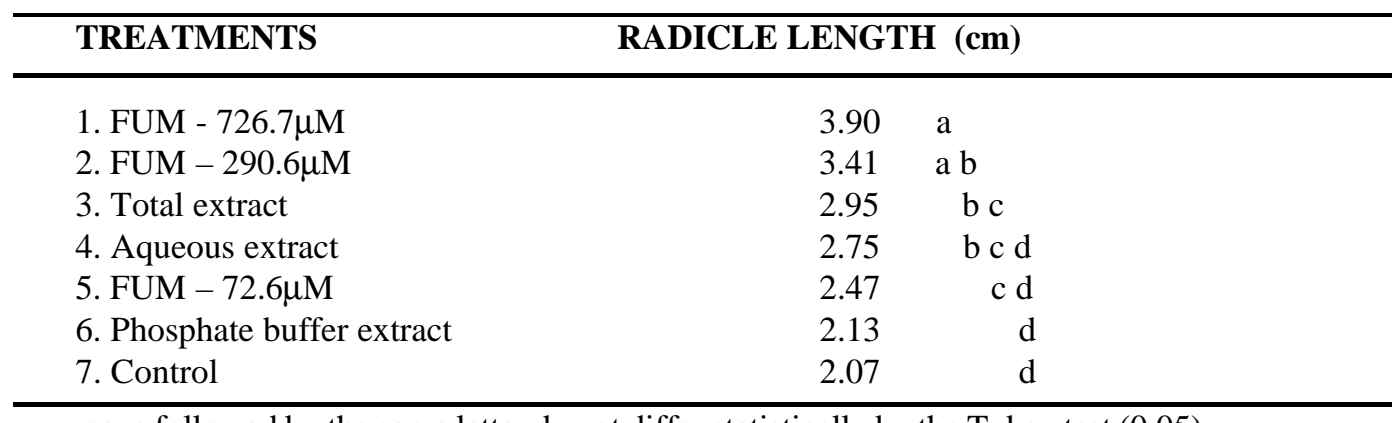

means followed by the same letter do not differ statistically by the Tukey test $(0,05)$.

Table 3 - Mean hypocotyl lenght of Allium cepa (cv. IPA 6) with fumarprotocetraric acid and C.verticillaris extracts.

\section{TREATMENTS HYPOCOTYL LENGTH $(\mathrm{cm})$}

1. FUM $-726.7 \mu \mathrm{M}$

2. FUM $-290.6 \mu \mathrm{M}$

3. Control

4. Aqueous extract

5. Total extract

6. FUM - 72.6 $\mu \mathrm{M}$

7. Phosphate buffer extract

$\begin{aligned} 5.38 & \text { a } \\ 5.03 & \text { a b } \\ 5.00 & \text { a b } \\ 4.27 & \text { b c } \\ 4.19 & \text { c } \\ 4.02 & \text { c } \\ 3.55 & \text { c }\end{aligned}$

means followed by the same letter do not differ statistically by the Tukey test $(0,05)$.

Table 4 - Data of HPLC from Cladonia verticillaris (Raddi) Fr. extracts.

\begin{tabular}{llll}
\hline EXTRACTS & SUBSTANCES & $\begin{array}{l}\text { RETENTION TIME } \\
(\mathbf{m i n})\end{array}$ & $\begin{array}{l}\text { ÁREA } \\
(\mathbf{\%})\end{array}$ \\
\hline * Aqueous & menthyl $\beta$-orcinol carboxilate & 0.93 & 41.9 \\
& fumarprotocetraric acid & 1.47 & 58.1 \\
* Phosphate & & & \\
buffer & menthyl $\beta$-orcinol carboxilate & 0.89 & 67.39 \\
& fumarprotocetraric acid & 1.29 & 30.28 \\
& no identified & 1.94 & 1.09 \\
* Total & protocetraric acid & 2.75 & 0.057 \\
& menthyl $\beta$-orcinol carboxilate & 0.76 & 5.86 \\
& fumarprotocetraric acid & 1.39 & 78.57 \\
& protocetraric acid & 2.87 & 13.29 \\
& atranorin & 5.56 & 2.18
\end{tabular}


fumarprotocetraric acid and $41.9 \%$ of methyl $\beta$ ornicol carboxilate (Table 4).

Phosphate buffer extract - In the phosphate buffer extract it was recorded the presence of protocetraric acid at very low concentration $(0.057 \%)$ and of a non identified substance in the retention time of $1.94 \mathrm{~min}$. With approximately $1.09 \%$. In this extract, methyl $\beta$ orcinol carboxilate increases its concentration to $67.39 \%$ while fumarprotocetraric acid decreases, remaining with $30.28 \%$ (Table 4).

Total extract - It is found in the total extract, the appearance of protocetraric acid (13.29\%) again, and the first record of atranorin with $2.18 \%$ of the composition, $5.86 \%$ and $78.57 \%$ of methyl $\beta$-orcinol carboxilate and fumarprotocetraric acid, respectively (Table 4).

\section{Discussion}

Although several former works with lichenic extracts (Rondon, 1966; Dauriac and Rondon, 1976; Tolpysheva, 1984a, 1984b and Vainshtein and Tolpysheva, 1992), including the phosphate buffer extract (Vicente, 1988) have produced biological activity, the absence of stimulatory or inhibitory effect of these extracts on the germination rate corroborate the idea that the chemical composition and the concentration are responsible for the biological response of the lichen.

In our investigation significant differences were find by HPLC-analyses among the three type of C. verticillaris thallus extracts. In the aqueous extract the presence of only two substances demonstrated clearly, that the fumarprotocetraric acid, although a lichenic acid, show much solubility in water, in agreement with (Iskandar and Syers 1971) and (Ascaso et al. 1986). In the phosphate buffer extracts, the above mentioned substances were also present, but at different concentrations. In addition, the different chemical substances present in the extracts in small amounts, like protocetraric acid, non identified substances and atranorin, the latter present in the total extract, according to (Geyer and Feige 1987) are biogenetically related. This fact can be evidenced in the total extract where protocetraric acid $(13.29 \%)$ is likely to influence directly the concentration of fumarprotocetraric acid, since it is produced from its hydrolysis (Huovinen et al., 1983), and, indirectly, the concentration of methyl $\beta$-orinol carboxilate, since it is the precursor of fumarprotocetraric acid (Xavier-Filho et al., 1985). In the total extract, Asahina (1943) and Culberson (1969) recorded only the presence of fumarprotocetraric acid in $C$. verticillaris. However, our result show the presence of other substances (Table 4). Probably, the methodology emplloyed in the extraction was responsible for the presence of other substances. This hypothesis was corroborated by the works of (Xavier Filho et al. 1984) show the presence of the orcinol, methyl $\beta$-ornicol carboxilate, atranorin and evernic acid, and (Vicente and Xavier Filho 1979); Huovinen et al. (1990) and (Ahti et al. 1993), who found fumarprotocetraric acid and other substance also, named Cph 2.

In our investigation, the pure fumarprotocetraric acid at $290.6 \mu \mathrm{M}$ and $72.6 \mu \mathrm{M}$ shows the greatest germination rates, though not statistically different. Comparing the fumarprotocetraric acid concentration in the aqueous extract with the $72.6 \mu \mathrm{M}$ concentration (Table 4), they show near values, but the responses shown in germination were different. Due to this fact, it can be suggested that methyl $\beta$-orcinol carboxilate, with approximately $41.9 \%$ of the aqueous extract, presents an antagonistic effect to fumarprotocetraric acid. There are works indicating antiherbivorous (Reutimann and Scheidegger, 1987) and antineoplasm (Lima et al., 1990) activities of the fumarprotocetraric acid . Results obtained in the present work suggest that the decrease in cellular proliferation found in animal cells by (Lima et al. 1990) probably did not occur in this study, since the high means obtained in seedling length are possibly a result of increase in cell division and/or elongation. As previously discussed, the methyl $\beta$-orcinol carboxilate seems to neutralise the effect of fumarprotocetraric acid, what can be observed in the treatment with the phosphate buffer extract regarding the length of the hypocotyl. In this extract, methyl $\beta$-orcinol carboxilate is in higher concentration, with appoximately $67 \%$ of the 
extract composition and fumarprotocetraric acid with $30 \%$, the lowest concentration of this acid compared to the other extracts. (Caccamese et al. 1986) attribute to methyl $\beta$-orcinol carboxilate an antimicrobial activity. If this activity includes antimitotic activity as previously discussed, the results found in the present work are according to what was expected. It is emphasizing that the phosphste buffer extract showed a significant inhibition on the hypocotyl length (Table 3), probably relates to cell division and/or elongation. Our results can contribute for future studies on the action of these secondary substances, since the stimulatory and/or inhibitory effects obtained can be indirect, mediated by plant hormones, enzymes, protein synthesis and/or through the modification of the membrane permeability.

\section{Acknowledgements}

The authors want to thanks Dr. Vania Canuto (EMBRAPA/IPA, Brazil), for having made available the facilities of the seed Lab of the Agricultural Research Agency of Pernambuco for the germination tests; Dr. Marçal de Queiroz Paulo (Dept. of Chemistry, UFPB, Brazil), for his criticism and suggestions; Dr. Eduardo Assis Menezes (EMBRAPACPATSA, Brazil), for the review of the manuscript, and CAPES (Coordenação de Aperfeiçoamento de Níveis Superior), for the financial support.

\section{Bibliography}

Ahti, T.; Stenroos, S.; Xavier-Filho, L. 1993. The lichen family Cladoniaceae in Paraíba, Pernambuco and Sergipe, northeast Brazil. Tropical Bryology, 7: 55-70.

Asahina, Y. 1943. Chemismus der Cladonien unter besonderer Berucksichtigung der Japanischen Arten (Fortsetzung). Journal of Japanese Botany, 49: 227-244.

Asahina, Y.; Shibata, S. 1954. Chemistry of lichen substances. Tokyo: Japan Society for the Promotion of Science, 240p.

Ascaso, C.; Galvan, J. 1986. Studies on the pedogenetic action of lichen acids. Pedobiologia, 16(5): 321-331

Brown, R.T. \& Mikola, P. 1974. The influence of fruticose soil lichens upon the mycorrhizae and seedling growth of forst trees. Acta Forestalia Fennica, 191: 5-23.
Caccamese, S.; Compagnini, a ; Toscano, R. M.; Cascio, O. 1986. Methil $\beta$-ornicol carboxilate and atranol from the lichen Sterocaulon vesuvianum. Journal of Natural Products, 49(6): 1159-1160.

Culberson, C.F. 1969. Chemical and botanical guide to lichen products. University North of Carolina Press: Chapel Hill 628p.

Dauriac, H.; Rondon, Y.1976. Quelques aspects des propriétés d'un lichen, le Letharia vulpina (L.)Hue, en biologie végétale expérimentale.I. Action sur la germination du blé et le développement de l' ali. Bulletim de la Societe Botanique de France, 123: 235-241.

Fisher, R.F. 1979. Possible allelopathic effects of reinder-moss (Cladonia) on jack pine and white spruce. Forest Science, 25(2), 256-260.

Garcia-Junceda, E.; Xavier-Filho, L. 1986. Solubilizationof lichen phenolics from Cladonia sprucei by simulated rainfall. Lichen. Physiol. Biochen., 01:61-69.

Geyer, M.; Feige, G. B. 1987. Analysis of depsides, depsidonas, and other lichen specific aromatics by high performance liquid chromatography. Bibliotheca Lichenologica, 25: 467-468.

Giez, I; Lange, O.L.; Proksch, P. 1994. Growth retarding activity of lichen substances against the polyphagous herbivorous insect Spodoptera littoralis. Biochemical Systematic Ecology,22(2): 113-120.

Goldner, W.R.; Hoffman, F.M.; Medve, R. J.1986. Allelopathic effects of Cladonia cristatella on ectomycorrhizal fungi commom to bituminous strip-mine spoils. Canadian Journal of Botany,64: 1586-1590.

Huneck, S. 1973. Nature of lichens substances. In: AHMADJIAN, V.; HALE, M. E. (eds.) The lichen. London: Academic Press. 697p.

Huovinen, K.; Hilten, R. Schantz, M. 1983. Analysis of lichen acids from extracts of Cetraria islandica by high performance liquid chromatography. In: Gesamtkongress der Pharmazeutischen Wissenschaften Die in der Arzneimitielforschung. Abstracts, p. 294.

Huovinen, K. Ahti, T.; Stenroos, S. 1990. The composition and contents of aromatic lichen substances in Cladonia section Cladonia and group Furcatae. Bibliotheca Lichenologica, 38: 209-241.

IsKandar, I.K.; Syers, J.K. 1971. Solubility of lichen compounds in water: pedogenetic implication. Lichenologist, 05: 45-50

Lima, R.C.; Nascimento, S. C.; Pereira, E. C. G.;Campos-Takaki, G. M. 1990. Atividade citotóxica e antitumoral de extratos liquênicos. Boletim da Sociedade Broteriana, 63(2): 339-348. 
Pyatt, F.B. 1967.The inhibitory influence os Peltigera canina on the germination of graminaceous seeds and the subsequent growth of the seedlings. The Bryologist, 70(3): 326-329.

Putnam, A.R. 1985.Allelopathic research in agriculture: past highlights and potential. In: Thompson, A.C. (ed) The chemistry of allelopathy biochemical interaction among plants. Washington : American Chemical Society. Cap.01, 470p.

Reutimann, P.; Scheidegger, C. 1987. Importance of lichen secondary products in food choice of two oribatid mites (Acari) in an alpine meadow ecosystem. Journal of Chemical Ecology, 13(2): 363-369.

Roger, M.J.R.; Ocaña, A C. 1992. La alelopatia y su papel en las comunidades vegetales. Revisión crítica, metodológica y bibliográfica. Santiago de Compostela: Universidade. Serviço de Publicacions e intercambio científico, 109p.

Rondon, Y. 1996 Action inhibitrice de 1' extrait du lichen Roccella fucoides (Dicks) Vain sur la germination. Bulletim de la Societe Botanique de France, 113: 01-02

Rundel, P.W. 1978. The ecological role of secondary lichen substances. Biochemical Systematics and Ecology, 06: 157-170.

Schatz, A. 1963. Soil microorganisms and soil chelation. The pedogenic action of lichens and lichen acids. Agricultural and Food Chemistry, 11(2): 112-118.

Syers, J.K. 1969. Chelating ability of fumarprotocetraric acid and Parmelia conspersa. Plant and Soil, 31(1): 205-208.

Tolpysheva, T.Yu. 1984a Effects of lichen extracts on fungi. I. Effects of aqueous extracts of Clandina stellaris and $C$. rangiferina on growing soil fungi. Mikologia i Fitopatologiya, 18(4): 287-293.

Tolpysheva, T.Yu. 1984b Effects of lichen extracts on fungi. II. Effects of joint preparation obtained from Clandina stellaris and C. rangiferina on growing soil fungi. Mikologia i Fitopatologiya, 18(5): 384-388.

Vainshtein,; Tolpysheva, T. Yu. 1992. The effects of lichen extract of Hypogymia physodes (L.) Nyl. And pure lichen acids on wood destroying fungi. Mikologia i Fitopatologiya, 26(6): 448-455.

Vicente, C. 1988. Polissacarídeos carcinostaticos y antibioticos procedentes de liquenes. IN: MEZO, M. ${ }^{a} G$. (Coord.) Curso de investigacion de farmacos. Granada: Universidade de Granada, Instituto de Ciências de la Educacion.p. 153-189.

Vicente, C.; Xavier-Filho, L. 1979. Urease regulation in Cladonia varticillaris (Raddi) Fr. Phyton (Buenos Aires), 37: 137-144.

Xavier-Filho, L.; Arruda, E. C.; Paulo, M. Q.;
Legaz, M. E.; Vicente, C. 1984. Chemotaxonomical study on Cladonia verticillaris (Raddi) Fr. And Cladonia calycantha (Del) Nyl. Phyton (Buenos Aires), 44(2): 115-119.

Xavier-Filho, L. Paulo, M.Q.; Vicente, C. Legaz, M. E. 1985. Phenols from Cladonia sandstedei anlyzed by high performance liquid chromatography. Criptogamie, Bryologie et Lichenologie, 6(2): 143-149.

Whiton, J.C. \& Lawrey, J.D. 1982. Inhibition of Cladonia cristatella and Sordaria fimicola ascospore germination by lichen acids. The Bryologist, 85(2): 222-226.

Whiton, J.C. \& Lawrey, J.D 1984. Inhibition of crustose lichen spore germination by lichen acids. The Bryologist, 87(1): 42-43. 
